\title{
Long-term trends in production and composition of ryegrass-white clover pasture intensively grazed by dairy-beef cattle
}

\author{
G.P. COSGROVE \\ AgResearch Grasslands, PB 11-008, Palmerston North, 4442 \\ gerald.cosgrove@agresearch.co.nz
}

\begin{abstract}
A measure of pasture persistence is stability of yield and proportion of desirable species over a long period. Long-term data on animal production and pasture yield and composition of old permanent pasture in the Manawatu were examined for trends indicative of persistence. The data were collected from two sets of replicated 1.6-ha farmlets intensively grazed by dairybeef bulls stocked at 7.4 yearlings wintered/ha for 16 of 18 years from 1969-1986, and 11 years from 1978 and 1988, respectively. Annual total LWG, total yield of DM and the yields of ryegrass, white clover and other species showed year-to-year variation. There was no long-term decline in production indicating that for this environment and management system ryegrass and white clover were inherently persistent under intensive grazing at high stocking rates. These results are discussed in the context of anecdotal reports of poor persistence of modern cultivars, with particular emphasis on the effects that high stocking rates, intensive utilisation and defoliation management may have on persistence.
\end{abstract}

Keywords: cattle, grazing, pasture, persistence, ryegrass, white clover

\section{Introduction}

Ryegrass (Lolium perenne) and white clover (Trifolium repens) are perennial species. Both are considered tolerant of a broad range of defoliation management practices. Compared with many temperate pasture species they are more tolerant of animal treading (Edmonds, 1963, 1964). Intensive grazing has often been recommended as a way to create and maintain the dominance of these species, by reducing the abundance of other species through effects of treading and intensive defoliation. They are however susceptible to herbivory by a range of insect species such as grass grub (Costelytra zealandica), porina (Wiseana cervinata), argentine stem weevil (Listronotus bonariensis), black beetle (Heteronychus arator), and more recently clover root weevil (Sitona lepidus), to name a few. Both species require moderate to high fertility for optimum production, and are sensitive to water stress and high ambient temperatures.

Given the inherent characteristics of each species, and their plasticity in response to a broad range of management practices, the increasing frequency of anecdotal reports of poor persistence of modern cultivars (see Lane, 2010) is surprising. While there is limited scientific evidence to substantiate these reports, let alone enough to form hypotheses that might explain the observations, it is prudent to examine the possible basis for them and to consider possible explanations and propose solutions. There are many possibilities, such as changes in on-farm management practices, changes in the genetic and morphological characteristics of cultivars selected for higher dry matter yield, the replacement of wild-type endophytes with novel endophytes, and changes in the prevalence of insect damage. Another explanation could be an increasing awareness by farmers of changes over time in the botanical composition of recently sown pastures.

This manuscript examines trends in animal and pasture production from old, ryegrass-white clover dominant, permanent pasture grazed by dairy beef bulls over a period of 18 years. The primary purpose of these studies, commenced in 1968 by the late Dr Ray W. Brougham, was to examine the influence of various grazing management practices and pasture inputs on production in a series of seven, 3-year experiments. These studies applied the principles of pasture growth and utilisation developed by Brougham in smallplot studies, at a scale large enough to allow animal production to be measured. This retrospective analysis was based on data from two pairs of control farmlets used for each of the consecutive studies. The individual studies have been described elsewhere (Brougham et al. 1975; Cosgrove \& Brougham 1988; Cosgrove et al. 2003). In particular, a review of Ray Brougham's lifetime work (Harris 1996) provides background and context for these studies.

\section{Materials and Methods}

The studies reported in this paper were conducted at the Grasslands Division of the Department of Scientific and Industrial Research, Aorangi research farm $20 \mathrm{~km}$ west of Palmerston North. Alluvial soils at the site are predominantly Kairanga silt and sandy loams, with some Manawatu and Rangitikei sandy loams (Rijkse \& Daly 1972). Farmlet experiments, commencing in 
November 1968 and terminating in February 1989, investigated pasture production, utilisation and animal performance under intensive, highly-stocked, rotational grazing management systems. The 20-year (19701989) mean annual rainfall recorded $1 \mathrm{~km}$ from the experimental site was $860 \mathrm{~mm}$ ( \pm SD $129 \mathrm{~mm})$. The research area was drained with a newly installed tile and mole system, before the experiments started.

\section{Experimental design}

From November 1968 to February 1987, six farmlets (A farmlets) were used for four, 3-year experiments. Animal liveweight gain (LWG) was recorded for 16 years of the 18-year period (each annual cycle of animal production commenced with calves introduced to farmlets in November and removed 12-16 months later between November and February). Pasture records for the period 1969 to 1976 (a pasture production year is January-December) have been lost, but data for 8 consecutive years from 1979 to 1986 are available. No pasture or animal measurements were conducted during 1977 or 1978. In 1977 a further six farmlets (B farmlets) were added and these were used for three, 3-year experiments from November 1977 to February 1989. For each 3-year experiment involving comparisons of grazing management (winter loafing pads, summer grazing intensity) or responses to pasture inputs (nitrogen fertiliser, irrigation, pasture species/cultivars), the same two farmlets within each set of six were retained as replicate controls. Between successive experiments usually a year was allowed for re-adjustment from previous treatments or for sowing and establishing new experimental pastures. During these intervening down-years, the management and measurements on the undisturbed control farmlets continued as normal, thus providing 16 years of animal production (two periods of 8 consecutive years) and 8 years of pasture production for the A farmlets, and 11 years of continuous records of pasture and animal production for the $\mathrm{B}$ farmlets.

\section{Farmlets}

Each 1.62-ha farmlet was subdivided into eight, 0.2ha permanent paddocks. Within paddocks further subdivision with temporary electric fencing was used throughout autumn, winter and spring to ration feed allocation. Each farmlet was stocked with 12 weaned 3-month-old Friesian dairy bull-beef calves $(70-90 \mathrm{~kg}$ LW) in early November each year, grazing as leaders. Fifteen-month-old bulls (i.e. the calves added the previous year), grazing as followers, were progressively removed for slaughter from November-February each summer, to match animal feed demand with pasture supply (i.e. a variable stocking rate during Nov-Feb).
From March-October each farmlet contained a single age-class of rising-yearling bulls wintered at 7.4/ha (i.e. a fixed stocking rate during Mar-Oct). For the final year commencing in November 1987, the stocking rate in the B farmlets was reduced to 5.55/ha (nine/farmlet).

\section{Pastures}

Before the experiments began in November 1968 the resident pastures were described as run-out, 20 -years-old and predominantly perennial ryegrass and white clover with a significant browntop (Agrostis capillaris) content, indicative of low fertility and poor pasture management. Regular application of $250 \mathrm{~kg} /$ ha of superphosphate $(9 \% \mathrm{P}, 11 \% \mathrm{~S})$ in autumn was commenced in 1969 (30\% potassic-super applied in 1969). The experimental area for $A$ farmlets was oversown with Manawa hybrid ryegrass $(17 \mathrm{~kg} / \mathrm{ha})$ and Huia white clover $(2.2 \mathrm{~kg} / \mathrm{ha})$ in August 1968. Lime was applied at $3.7 \mathrm{t} / \mathrm{ha}$ in autumn 1970, and again at a similar rate in about 1981. Soil chemical characteristics were assessed as part of other studies conducted within the A farmlets (see Crush et al. 1982; Carran \& Theobald 1995, 2000), and the B farmlets (see Crush et al. 1983).

With the exception of the first 2 years of the A farmlets $(1969,1970)$ no pasture was conserved, and no supplements were brought-in. Hay was conserved and fed in the first 2 years, potentially contributing seed input from mature pasture as the hay was made, and fed. This practice was discontinued because at the high stocking rate there was no genuine surplus of pasture, and high utilisation and spelling intervals no longer than 32 days largely precluded stem development. However, for one rotation during Nov-Dec paddocks were topped after grazing to remove any patches of uneaten or laxly grazed residue.

Although these studies were conducted before the link between endophyte and ryegrass staggers was made, staggers was prevalent, indicating that the resident ryegrass contained wild-type endophyte.

\section{Grazing management}

The management tools to match pasture supply with demand consisted of i) rationing feed as described below, manipulating the spelling interval, and so the area allocated for grazing each day, according to pasture growth rate and ii) varying the stocking rate of bulls in late-spring initially by the addition of calves to increase grazing pressure and utilisation in late-spring, and then by the progressive removal of 15-19-month old bulls during summer to reduce grazing pressure. Paddocks within farmlets were rotationally grazed in a fixed sequence throughout the year. The rotation length was longest in autumn at 64 days, comprised of four $x 2$-days 
grazing per break within each paddock and nominally 62 days spelling between successive grazings (no backfences were used), and shortest in spring at 24 days, comprised of three x 1-day breaks per paddock and 23 days spelling. Rotation length was progressively shortened during winter to 48 (three, 2-day breaks per paddock), 40 days (five daily breaks) and then 32 days (four daily breaks) per rotation, as pasture accumulation rates decreased. During summer it was lengthened to 40 days consisting of 4 days grazing by calves as 'leaders' and 4 days by bulls as 'followers' and 32 days spelling. The decreasing pasture accumulation rate was balanced by the removal of 15-19-month bulls to equate demand with supply.

\section{Measurements}

Pasture accumulation was measured using grazing exclosure cages. Three $1.8 \times 0.9 \mathrm{~m}$ cages in each of three paddocks (of eight) on each farmlet were cut to grazing height when animals had finished grazing that particular paddock. Each cage was then repositioned on a grazed area within that paddock so as to reflect regrowth of grazed pasture rather than cut pasture. The herbage cut from the three caged areas was composited, weighed, and a subsample taken and oven dried at $85^{\circ} \mathrm{C}$ to determine dry weight and herbage mass/ha. A further subsample was dissected into ryegrass, white clover, other grasses, other species and dead material, ovendried to determine the proportion of these components in the herbage. The mean estimate of pasture consumed for each of the three paddocks within each rotation was summed for the eight to nine rotations annually to estimate total annual consumption per hectare.

Pasture utilisation was estimated from pasture quadrat cuts to ground level, before and after grazing of one of the breaks in the same three paddocks as the exclosure cages (in summer these estimates related to grazing by bulls, until the estimated total feed demand by bulls was less than by calves - approximately when three or fewer bulls remained). These measurements were conducted for 5 consecutive years in the A farmlets (commencing September 1 1979), and two periods of 2 consecutive years in the B farmlets (commencing September 1 1978, and September 1 1982). Initially, this was by cutting $30 \times 0.1 \mathrm{~m}^{2}$ randomly-located quadrats. Later this was superseded by cutting three $x 0.25 \mathrm{~m}^{2}$ quadrats, each located at a site selected to represent the mean reading of 50 capacitance-probe readings taken in that break. This procedure was further modified by cutting $10 \times 0.25 \mathrm{~m}^{2}$ quadrats placed to represent a range from low to high herbage mass, and the linear relationship of quadrat yield regressed on probe reading used to estimate mass from the paddock-mean reading of the capacitance probe. All samples were washed to remove soil and faecal contamination, weighed and a subsample oven-dried for calculation of herbage mass.

Animal production, expressed as net LWG/ha/yr, was estimated from the liveweight of bulls, after fasting for $16 \mathrm{~h}$, at the time they were removed from the farmlets in summer, minus the fasted liveweight of those same animals when they were added to farmlets as calves in November 12-15 months earlier. While each generation of animals grazed the farmlets for up to 16 months, the turnover occurred each year, hence described as annual LWG.

\section{Statistical analysis}

For annual total LWG and total and component DM yields, the relationship between the deviation of each annual total from the overall mean and year of study (commencing from 1969=Year 1) was modelled by a generalised additive mixed model (Wood 2010) where there was a nonlinear trend, and by a linear mixed effects model (Bates 2010) where there was a linear trend. Rainfall and year were the fixed effects and replicate was the random effect. For each measurement at each year, a predicted value together with $95 \%$ confidence interval was obtained and plotted on the graphs. For linear trends the slope of the relationship is the rate of change per year. For nonlinear trends, a horizontal line at the overall mean $(\mathrm{Y}=0)$ is included to indicate the pattern of deviations from the overall mean. The mean pre-grazing and post-grazing herbage mass for each of 9 grazing rotations (3 measurements per rotation) from September 1 (approximately 1 year duration) for the A farmlets (5 years data) and the B farmlets (4 years data) was modelled by the generalised additive model and a predicted value and $95 \%$ confidence interval plotted.

\section{Results \\ A farmlets \\ Liveweight gain}

The overall mean was $1968(\mathrm{SD} \pm 213) \mathrm{kg} \mathrm{LWG} / \mathrm{ha} /$ yr. Annual LWG/ha remained stable (slope of the linear relationship not significantly different from 0 ) over 18 years (Fig. 1a).

\section{Dry matter yield and composition}

Total annual yield (overall mean $15.9 \pm 1.9$ t DM/ha; data covers years 11-18) was higher during years 12 and 13 (i.e. $95 \%$ confidence interval (CI) did not include 0 ), but declined and was slightly below the mean in other years (Fig. 1b). Ryegrass yield $(9.5 \pm 1.6 \mathrm{t} \mathrm{DM} / \mathrm{ha})$ declined linearly (Fig. 1c; slope significantly less than 0 ), compensated by a tendency for other grasses (4.2 $\pm 1.6 \mathrm{t} \mathrm{DM} / \mathrm{ha}$ ) to increase (Fig. 1e). For white clover $(2.5 \pm 0.7 \mathrm{t} \mathrm{DM} / \mathrm{ha})$ there was a cycle of high yields during years 12-14, and low yields during years 15-17 
Figure 1 Predicted linear or non-linear relationships between annual net liveweight gain (kg/ha) (a), total annual dry matter (DM) yield (kg DM/ha; b), ryegrass annual DM yield (c), white clover annual DM yield (d), other grasses annual DM yield (e), other species annual DM yield $(f)$ and dead matter annual DM yield $(g)$ and cumulative year of measurement for the $A$ farmlets. The $\mathrm{Y}$-axis units are deviation from the overall mean, shown as the horizontal line at $\mathrm{Y}=0$ (excluding a, c, e and $\mathrm{g}$ where the straight line relationship is shown) and the dotted curves indicate the $95 \%$ confidence interval for the estimates of annual yield. Open circles indicate the specific values for each replicate in each year.

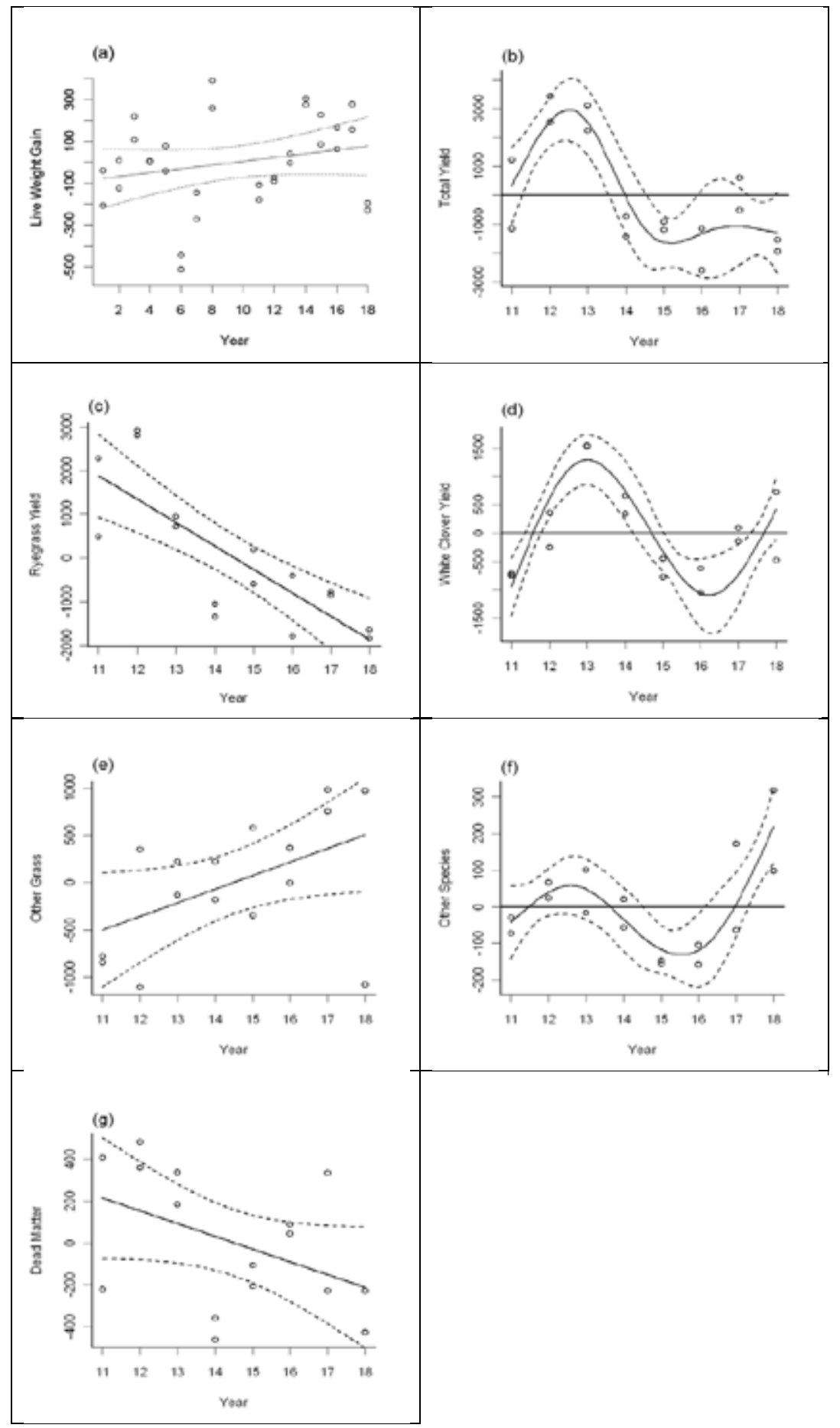


Figure 2 Predicted linear or non-linear relationships between annual net liveweight gain $(\mathrm{kg} / \mathrm{ha})(\mathrm{a})$, total annual dry matter (DM) yield (kg DM/ha; b), ryegrass annual DM yield (c), white clover annual DM yield (d), other grasses annual DM yield (e), other species annual DM yield $(f)$ and dead matter annual DM yield $(g)$ and cumulative year of measurement for the $B$ farmlets. The $\mathrm{Y}$-axis units are deviation from the overall mean, shown as the horizontal line at $\mathrm{Y}=0$ (excluding $\mathrm{c}$ and e where the straight line relationship is shown) and the dotted curves indicate the $95 \%$ confidence interval for the estimates of annual yield. Open circles indicate the specific values for each replicate in each year.

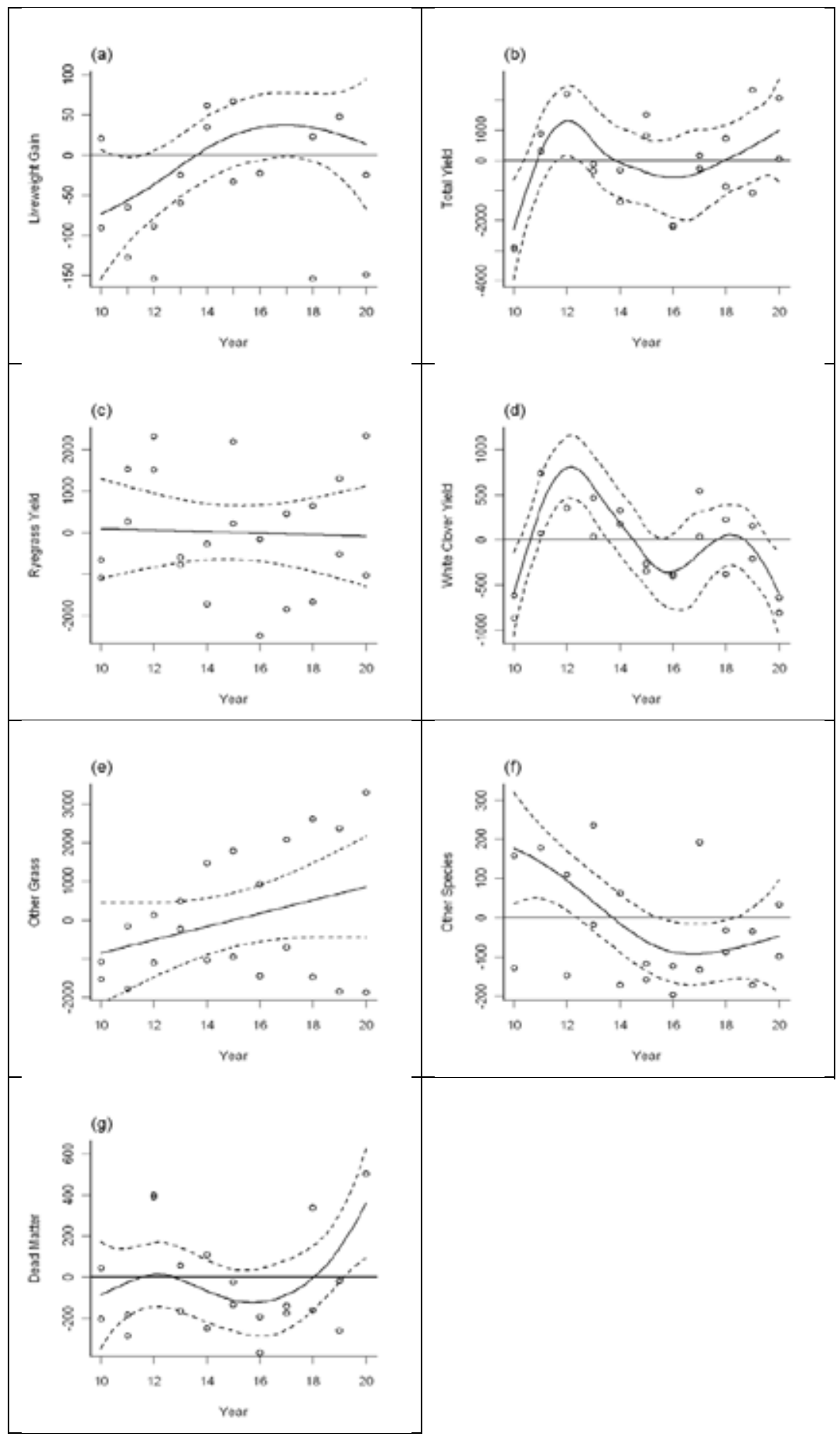


Figure 3 The predicted annual profile of mean pre-grazing (solid line) and post grazing (broken line) herbage mass and the $95 \%$ confidence interval for the predicted means shown as the shaded bands, for each grazing rotation from September 1 for the $A$ farmlets (data are the mean of 5 consecutive years, 1979-84).

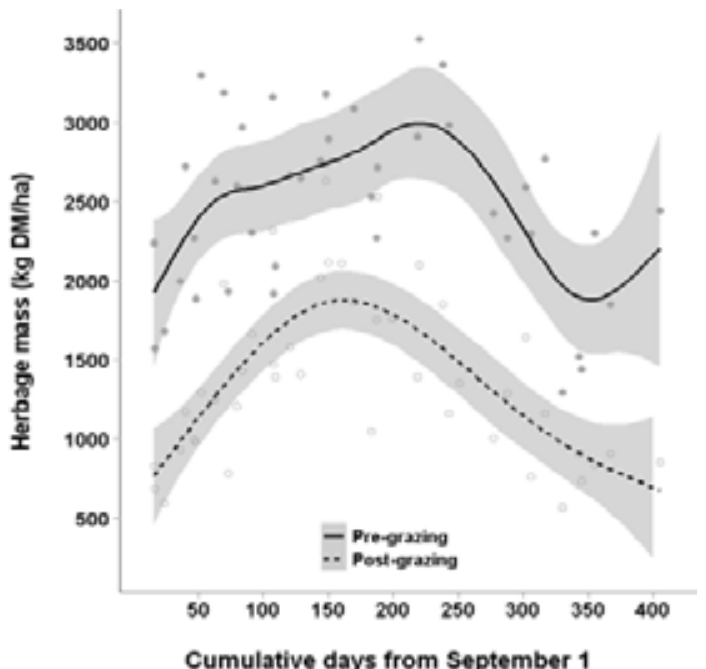

(Fig. 1d). The yield of other species $(0.3 \pm 0.1 \mathrm{t} \mathrm{DM} /$ ha; Fig. 1f) fluctuated in a less regular manner, but dead matter $(1.1 \pm 0.3 \mathrm{t} \mathrm{DM} / \mathrm{ha})$ declined linearly (Fig. $1 \mathrm{~g})$.

\section{B farmlets}

\section{Liveweight gain}

The overall mean was 1895 (SD \pm 113$) \mathrm{kg}$ LWG/ ha/yr over 11 consecutive years (years 10-20). The 95\% CI included 0 across all years, indicating no significant departure from the overall mean. However, the curvilinear relationship (Fig. 2a) indicated annual LWG/ha increased during years 10-16, but trended downward during the last three.

\section{Dry matter yield and composition}

Apart from the low yield in the first year (i.e. for year 10 the $95 \%$ CI did not include 0 ), the total annual DM yield (Fig. 2b) did not differ significantly from the overall mean $(13.9 \pm 1.7 \mathrm{t} \mathrm{DM} / \mathrm{ha})$ for the 10 subsequent years of measurements (i.e. the $95 \% \mathrm{CI}$ included 0), and for the yield of ryegrass $(6.4 \pm 1.4 \mathrm{t} \mathrm{DM} / \mathrm{ha})$ the slope was not significantly different from 0 (Fig. 2c). The trend for white clover $(2.1 \pm 0.6 \mathrm{tDM} / \mathrm{ha})$ was more complex (Fig. 2d), with high yield in years 11-13. The yield of other grasses $(4.2 \pm 1.6 \mathrm{t} \mathrm{DM} /$ ha; Fig. 2e) increased linearly (dominated by the trend in one replicate only) and the yield of other species $(0.3 \pm 0.2 \mathrm{tDM} / \mathrm{ha})$ tended to decrease (Fig. 2f). Except for a greater abundance in the last year, dead matter $(0.9 \pm 0.3 \mathrm{t} \mathrm{DM} / \mathrm{ha})$ remained stable (Fig. 2g).
Figure 4 The predicted annual profile of mean pre-grazing (solid line) and post grazing (broken line) herbage mass and the $95 \%$ confidence interval for the predicted means shown as the shaded bands, for each grazing rotation from September 1 for the $B$ farmlets (data are the mean of 4 years, 1978-80 and 1982-84).

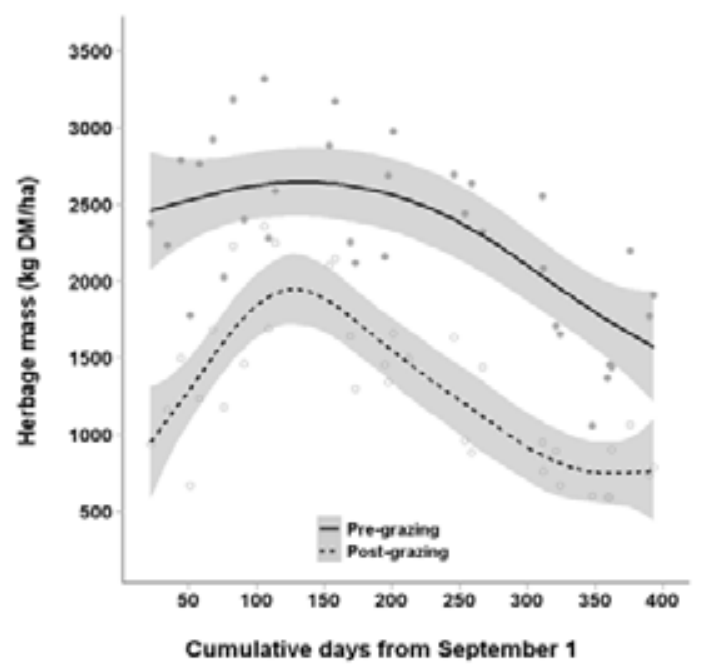

\section{Pasture mass and utilisation in $A$ and $B$ farmlets}

The overall annual mean ( \pm SD of means for each rotation) pre-grazing pasture mass was $2480 \pm 410$ and $2320 \pm 460 \mathrm{~kg} \mathrm{DM} / \mathrm{ha}$ and the mean post-grazing mass was $1360 \pm 420$ and $1300 \pm 450 \mathrm{~kg} \mathrm{DM} / \mathrm{ha}$ for the $\mathrm{A}$ and $\mathrm{B}$ farmlets, respectively. The mean removal of DM per grazing was approximately $1100 \mathrm{~kg} \mathrm{DM} /$ ha for both sets of farmlets. The annual profile of pre-and postgrazing mass indicated seasonal variation (Figs 3 \& 4), with pre-grazing mass up to $3000 \mathrm{~kg} \mathrm{DM} / \mathrm{ha}$ during autumn and post-grazing mass down to $600 \mathrm{~kg} \mathrm{DM} / \mathrm{ha}$ during late-winter.

\section{Discussion}

This study examined long-term trends in pasture and livestock production from old permanent pasture under an intensive high stocking-rate grazing management system (which includes grazing method, stocking rate and stock class as defined by McMeekan (1960)), designed from first principles of defoliation management. The extent to which this system sustained high levels of production is then used to deduce where current management systems may deviate from these principles of defoliation management and to consider explanations for recent observations by farmers of poor persistence of modern cultivars of perennial ryegrass and white clover. 


\section{System performance}

The high level of animal production (1968 and 1895 $\mathrm{kg} \mathrm{LWG/ha/yr} \mathrm{for} \mathrm{A} \mathrm{and} \mathrm{B} \mathrm{farmlets,} \mathrm{respectively),}$ maintained for up to 18 years, reputedly five times higher than the average yields of North Island fattening units at the time of the study (see Harris 1996), is the primary indication that the high stocking rate, intensive management system per se did not compromise the ability of the pastures (and soils) to sustain that high level of production. This is supported by the sustained total annual DM consumption in the B farmlets (overall mean $13.9 \mathrm{t} \mathrm{DM} / \mathrm{ha} / \mathrm{yr}$ ), although the total yield of the A farmlets (overall mean $15.9 \mathrm{t} \mathrm{DM} / \mathrm{ha} / \mathrm{yr}$ ) was low during years 14-18. The decline in yield of ryegrass in the A farmlets over time was partially compensated by increased yield of other species of grass, but these pastures became more ryegrass dominant in later years because the yield of ryegrass declined less than did the total yield (data not shown but can be derived from total and component DM yields). Much longer-term studies than those at Aorangi have also shown that total yield is more stable than the species composition (Silvertown et al. 2006). Perhaps in the studies analysed here the presence of other species of grass and broadleaf weeds buffered total yield in a way that does not occur in simple binary pasture mixes of ryegrass and white clover. If this is the case, fluctuations in the yield and composition of these simple mixtures would be more obvious to managers and help account for the observations of poor persistence.

Long-term trends in the yield of white clover are influenced by underlying cycles, which alone are not indicative of lack of persistence. White clover and ryegrass co-exist in grazed pasture, based on exploitation of soil mineral N (e.g., Walker et al. 1953; Harris \& Thomas 1973), and according to experimental observation (Rickard \& McBride 1986) and theoretical analysis (Thornley et al. 1995; Schwinning \& Parsons 1996a, b) the proportions of each oscillate at 3-5 year cycles. Such oscillation is evident in the annual yields of white clover in the A farmlets (8 years) and the B farmlets (11 years), and (perhaps coincidentally) yields were highest in both sets of farmlets during years 1214.

\section{Interpretation}

The pre- and post-grazing pasture masses reflect pasture accumulation rate and grazing management (including feed consumption). The management decision to increase rotation length in autumn each year from 40 days during summer to 64 days initially resulted in declining pasture residuals because of the restricted intake, and increasing pre-grazing pasture mass as reserves were built for winter. As a consequence, peak pre-grazing mass of $2500-3000 \mathrm{~kg} \mathrm{DM} / \mathrm{ha}$ was generally reached in early winter, and minimum postgrazing residuals occurred during late winter. The low residual in late winter does not appear to have negatively affected the ability of ryegrass or white clover to persist. On the contrary, intensive grazing at that time of the year is directly beneficial for maintaining a high proportion of ryegrass by reducing the abundance of other species of grass that do not tolerate the intensive defoliation and associated intensive treading (Edmond 1964). Comparatively frequent defoliation from latewinter is also beneficial to subsequent warm-season yield of white clover (Brougham 1960), by moderating inter-specific light competition from ryegrass at a time of year when clover growing pointdevelopment is just commencing.

In contrast, both frequent defoliation and low residuals during summer are detrimental to yield (Brougham, 1960; 1961) related to elevated apices of ryegrass during summer. In the Aorangi grazing system residuals were kept higher during summer by careful control of grazing pressure. This was achieved by the progressive removal for slaughter of 16 to 18 -monthold bulls as increasing ambient temperatures and moisture stress restricted pasture accumulation rates, and by rigorously maintaining spells of at least 32 days between successive grazings (each paddock was grazed by weaner calves as leaders for 4 days, then by older bulls as followers for 4 days, then spelled for 32 days). In one of the 3-year studies conducted within these systems, too high a grazing pressure in summer severely reduced LWG in both summer and autumn (see Cosgrove et al. 2003), and presumably pasture production also (pasture yield data for this study has been lost). If low residuals do contribute to poor persistence, it is likely that a combination of too frequent defoliation and too high a grazing pressure in summer, particularly on dairy farms where there is less opportunity to relieve grazing pressure through removal of stock, are underlying causes. Despite recommendations for grazing rotations of 28 to 30 days (Macdonald and Penno 1998), rotations of 21 to 25 days are common on many dairy farms in summer (C.B. Glassey pers. comm.). The use of supplements facilitates extending rotations to the recommended length (reducing the area available for grazing each day) by helping to maintain cow DM intake, but unless the supplements are used in conjunction with a feed pad (or sacrifice area) the longer rotation is often associated with low residuals that limit pasture regrowth and affect persistence, as shown by Brougham (1960).

While the decision criteria for grazing frequency (rotation length) and intensity (residual) developed by Brougham were based on leaf area index, pre- 
grazing and post-grazing pasture height and regrowth intervals, the criteria recommended to farmers today are pre- and post-grazing mass (e.g., Facts and Figures for NZ Dairy Farmers, DairyNZ), proportion of farm area to be grazed each day, e.g., Bryant and L'Huillier (1986) or stage of growth, e.g., the number of leaves per tiller, (Fulkerson and Donaghy 2001). Surprisingly, however (given the differing feeding constraints in beef compared with dairy systems), each method results in very similar grazing management decisions in terms of rotation lengths, pre-grazing and post grazing masses, and the amount and proportion of DM removed at each grazing. Whether grazing management decisions are based on previous or current criteria (e.g., Macdonald et al. 2010) is unlikely to result in substantial differences in defoliation management practice that could affect pasture persistence.

The studies analysed here were conducted before the discovery of fungal endophyte (Neotyphodium lotii) and the link with ryegrass staggers, however, the prevalence of ryegrass staggers was widespread (the incidence and severity was recorded each summer) indicating that the resident ryegrass contained wildtype endophyte. The presence of wildtype endophyte reduces preference (Edwards et al. 1993; Cosgrove et al. 2002) and may deter animals from grazing low into basal material, even when herbage mass or sward height does not limit intake (R. Watson, unpublished report). In the last decade, increased sowing of ryegrass cultivars containing selected strains of endophyte (e.g., AR1, AR37; see Easton et al. 2007) or that are endophytefree, that do not present the same deterrent effect as does the wild type strain, has been suggested to have allowed animals to graze to lower residuals in summer that further compromise the plants' ability to survive. While this may simply indicate a failure to adhere to recommended grazing practice, the interacting effects of endophyte status and defoliation management on plant growth responses require further study.

\section{Conclusions}

High yields of pasture and animal production were sustained for up to 18 years in a grazing management system based on the principles of maximising yield of mixed grass-legume pasture, intensive utilisation by grazing animals and efficient conversion to liveweight gain. There was no evidence that high stocking rate, or intensive utilisation of pasture, negatively affected yield or composition of the 20 to 40 -years-old resident, ryegrass-white clover dominant pasture, composed of early cultivars these species from c. 1950, or possibly of locally adapted ecotypes from earlier sowings. The resident populations of the dominant species were inherently persistent in this environment. In the context of anecdotal reports of poor persistence of modern cultivars, the analysis described here suggests that factors other than high stocking rate and intensive utilisation per se may be involved. Deviations from the principles of good defoliation management, such as grazing too frequently, and/or too intensely particularly under hot or dry conditions in summer may be implicated. The consequences of this practice that was detrimental to older cultivars may be even more detrimental to newer genetic material and should be investigated further. Changes in the optimum frequencies and intensities of defoliation required for newer cultivars of ryegrass and white clover as a consequence of selection for higher DM yields over 50+ years cannot be ruled out. The complex interactions between grasslegume associations and soil nitrogen may also support re-examination of optimum defoliation practices for modern cultivars growing under conditions where $\mathrm{N}$ inputs ( $\mathrm{N}$-fixation, $\mathrm{N}$-fertiliser) differ from those of earlier studies. The consequences of replacing wild type endophyte with non-toxic strains may also warrant re-examination of optimum defoliation practices.

\section{ACKNOWLEDGEMENTS}

The late Dr Ray Brougham designed and initiated this series of studies, assisted by the late Don Johnston in his role as Dairy Board Consulting Officer. Dr Don Causley and Dave Clark were involved as scientists. D. MacDougall, S. Crotty, T. Cooper, M. Whitcombe, J. McMillan L.E. Madgwick, G.P. Owens, J.S. Cudby, R.G.C. Maxwell and W.J. Thomas provided technical expertise during the conduct of these studies. Pasture botanical dissections were conducted by Yvonne Gray and staff of the Herbage Laboratory, DSIR Grasslands Division. John Koolaard and Dongwen Luo conducted the statistical analyses.

\section{REFERENCES}

Bates, D.; Maechler, M. 2010. Ime4: Linear mixedeffects models using S4 classes. R package version 0.999375-37/r1160. Accessed 24/2/2011. http://RForge-project.org/projects/lme4/.

Brougham, R.W. 1960. The effects of hard grazings at different times of the year on the productivity and species yield of a grass-clover pasture. New Zealand Journal of Agricultural Research 3: 125-136.

Brougham, R.W. 1961. Some factors affecting the persistency of short-rotation ryegrass. New Zealand Journal of Agricultural Research 4: 516-522.

Brougham, R.W.; Causley, D.C.; Madgwick, L.E. 1975. Pasture management systems and animal production. Proceedings of the Ruakura Farmers Conference 27: 65-69. 
Bryant, A.M.; L'Huillier, P.J. 1986. Better use of pastures. Proceedings of the Ruakura Farmers Conference 38: 43-51.

Carran, R.A.; Theobald, P.W. 1995. Nitrogen cycle processes and acidification of soils in grazed pastures receiving or not receiving excreta for 23 years. Australian Journal of Soil Research 33: 525-534.

Carran, R.A.; Theobald, P.W. 2000. Effects of excreta return on properties of a grazed pasture soil. Nutrient cycling in Agroecosystems 56: 79-85.

Clark, D.A.; Causley, D.C.; Brougham, R.W. 1979. Nitrogen fixation in pasture VI. Manawatu Plains Kairanga. New Zealand Journal of Experimental Agriculture 7: 23-25.

Cosgrove, G.P.; Brougham, R.W. 1988. Pasture strategies for dairy-beef production. Proceedings of the New Zealand Grassland Association 49: 57-62.

Cosgrove, G.P.; Anderson, C.B.; Phillot, M.; Nyfeler, D.; Hume, D.E.; Parsons, A.J.; Lane, G.A. 2002. The effect of endophyte alkaloids on diet selection by sheep. Proceedings of the New Zealand Society of Animal Production 62: 167-170.

Cosgrove, G.P.; Clark, D.A.; Lambert, M.G. 2003. High production dairy-beef cattle grazing systems: a review of research in the Manawatu. Proceedings of the New Zealand Grassland Association 65: 21-28.

Crush, J.R.; Cosgrove, G.P.; Brougham, R.W. 1982. The effect of nitrogen fertiliser on clover nitrogen fixation in an intensively grazed Manawatu pasture. New Zealand Journal of Experimental Agriculture 10: 395-399.

Crush, J.R.; Cosgrove, G.P.; Brougham, R.W. 1983. Nitrogen fixation during 1979-81 in two pastures on the Manawatu plains. New Zealand Journal of Experimental Agriculture 11: 17-20.

Easton, H.S.; Thom, E.R.; Bluett, S.J.; Hume, D.E.; Popay, A.J. 2007. Endophyte technology for dairy pastures. pp. 293-306. In: Meeting the challenges for pasture-based dairying. Proceedings of the $3^{\text {rd }}$ Dairy Science Symposium. Eds. Chapman, D.F.; Clark, D.A.; Macmillan, K.L.; Nation, D.P. National Dairy Alliance, Melbourne.

Edmonds, D.B. 1963. Effects of treading perennial ryegrass and white cover pastures in winter and summer at two soil moisture levels. New Zealand Journal of Agricultural Research 6: 265-276.

Edmonds, D.B. 1964. Some effects of sheep treading on the growth of 10 pasture species. New Zealand Journal of Agricultural Research 7: 1-16.

Edwards, G.R.; Lucas, R.J.; Johnson, M.R. 1993. Grazing preference for pasture species is affected by endophyte and nitrogen fertility. Proceedings of the New Zealand Grassland Association 55: 137-141.
Fulkerson, W.J.; Donaghy, D.J. 2001. Plant soluble carbohydrate reserves and senescence - key criteria for developing an effective grazing management system for ryegrass-based pastures: a review. Australian Journal of Production Agriculture 41: 261-275.

Harris, W.; Thomas, V.J. 1973. Competition among pasture plants III. Effects of frequency and height of cutting on competition between white clover and two ryegrass cultivars. New Zealand Journal of Agricultural Research 16: 49-58.

Harris, W. 1996. The contributions of Dr Raymond Wilkie Brougham to grassland science and management. Proceedings of the New Zealand Grassland Association 58: 23-48.

Lane, P.M.S. 2010. Observations and insights on pasture persistence in New Zealand. Pasture Persistence. Grassland Research and Practice Series 15: 47-51.

Macdonald, K.A.; Penno, J.W. 1998. Management decision rules to optimise milksolids production on dairy farms. Proceedings of the New Zealand Society of Animal Production 58: 132-135.

Macdonald, K.A.; Glassey, C.B.; Rawnsley, R.P. 2010. The emergence, development and effectiveness of decision rules for pasture-based dairy systems. pp 199-209. In: Meeting the challenges of pasture-based dairying. Proceedings of the $4^{\text {th }}$ Australasian Dairy Science Symposium. Eds Edwards, G.R. and Bryant, R.H.

McMeekan, C.P. 1960. Grazing management. pp 2126. In: Proceedings of the $8^{\text {th }}$ International Grassland Congress.

Rijkse, W.C.; Daly, B.K. 1972. Soils of the Aorangi experimental farm, Manawatu district, New Zealand. New Zealand Journal of Agricultural Research 15: 117-136.

Rickard, D.S.; McBride, S.D. 1986. Irrigated and nonirrigated pasture production at Winchmore. Technical Report 21. Winchmore Irrigation Research Station.

Schwinning, S.; Parsons, A.J. 1996a. Analysis of the co-existence mechanisms for grasses and legumes in grazing systems. Journal of Ecology 84: 799-813.

Schwinning, S.; Parsons, A.J. 1996b. A spatially explicit population model of stoloniferous $\mathrm{N}$-fixing legumes in mixed pasture with grass. Journal of Ecology 84:815-826.

Silvertown, J.; Poulton, P.; Johnstown, E.; Edwards, G.; Heard, M.; Biss, P. 2006. The Park Grass Experiment 1856-2006: its contribution to ecology. Journal of Ecology 94: 801-814.

Thornley, J.H.M.; Bergelson, J.; Parsons, A.J. 1995. Complex dynamics in a carbon-nitrogen model of a grass-legume pasture. Annals of Botany 75: 79-94. 
Walker, T.W.; Adams, A.F.R.; Orchiston, H.D. 1953. The use of fertilisers on herbage cut for conservation IV. The effect of rates, methods of application and forms of fertiliser nitrogen on the yields of dry matter and nitrogen of grasses and clovers in a ryegrass and white clover sward cut at different stages of growth. Journal of the British Grassland Society 8: 281-299.
Wood, S. 2010. Gamm4: Generalized additive mixed models using mgev and lme4. R package version 0.1-0. Accessed 24/2/2011. http://CRAN.R-project. org $/$ package $=$ gamm 4 . 